\title{
Topic Recommendation Method related to a Present Topic for Continuing a Conversation
}

\author{
Wataru Sunayama $^{*}$, Yuki Shibata ${ }^{\dagger}$, Yoko Nishihara $^{\ddagger}$,
}

\begin{abstract}
This paper proposes a topic recommendation method. The methods recommends next topics related to a present topic. The purpose of the proposed method is to support to continue conversations. The proposed method detects spoken words of two users, makes a log text of the spoken words. Then, the method extracts a present topic from the log text, and evaluates relations between the present topic and next topic candidates. The method chooses next topics and recommends them to the users. The proposed method has been realized as a conversation support system that has an interface of Head Mounted Display (HMD) showing the log text, a word of the present topic, and words of the next topic. One of the users of the system wearing the HMD can grasp what topic is talked, and can choose a next topic from recommended them. The users can continue a conversation by talking about recommended topics. Experimental results showed that the realized system could support to continue conversations. We also found that the realized system supported users to obtain equal chances to speak.
\end{abstract}

Keywords: Conversation support, Head mounted display, Speech recognition, Topic recommendation

\section{Introduction}

Conversation is a basic method to exchange and obtain new information from others. People at school, at office, at hospital, and everywhere need to talk with others. It is better to talk with a person for the first time than to talk with a friend. Because it may be a chance of obtaining new information from the person.

There are some of people who unfortunately are weak at talking with a person for the first time. Though they can talk with their families and their familiar friends, they feel pain in talking with an unfamiliar person or a person for the first time. When they meet an unfamiliar person, they can say "Hi," but can not continue to talk with the person. They often make a silence of conversation as soon as they talk. The silent time of conversation may be not comfortable for them. It is desirable that they can talk with anyone comfortably without making the silent time.

\footnotetext{
* The University of Shiga Prefecture, Shiga, Japan

$\dagger$ Hiroshima City University, Hiroshima, Japan

\# Ritsumeikan University, Shiga, Japan
} 
This paper proposes a method that recommends next topics of a conversation. The purpose of the proposed method is to support to continue a conversation with a person for the first time. What function is necessary for the proposed method to support to continue conversations? Next section will discuss the required functions through case studies.

\section{Case studies for Discussing functions of the proposed method}

This section discusses problems that would happen in conversations by two persons for the first time. We would like to discuss functions that could solve the discussed problems, and would like to equip the functions to the proposed method.

\subsection{Case study 1}

John is a fourth grade student of H University. John feels negatively making conversations, and always thinks to become good at making conversations. John has hoped to join $\mathrm{S}$ laboratory that researches conversation support systems. He successfully has joined to $S$ laboratory. Professor S has invite new faces to the laboratory. John goes to the laboratory, and finds that the members of the laboratory are not familiar with him. John thinks that starting off on the right foot is essential. He starts to talk with Cathy next to him.

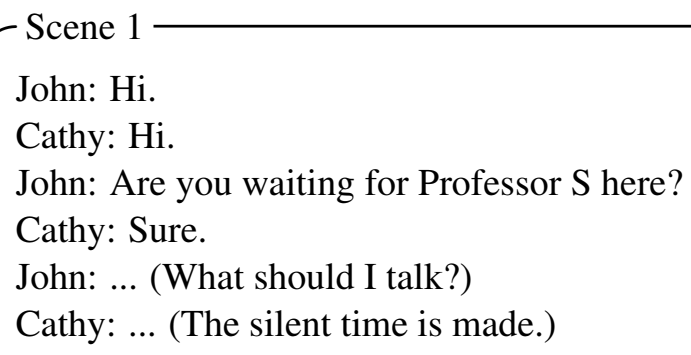

John can say "Hi", but he can not find what topic he should talk about. Therefore, they does not start to talk. In this case study, the problem is that John can not find what he should talk about. To solve the problem, he should be supported by giving topics what he should talk about.

\subsection{Case study 2}

After a while, Mary comes in the laboratory. John knows that Mary loves comics. So, he tries to talk with Mary about comics.

Scene 2

John: Hi, Mary. What comics have you read lately?

Mary: Now, I often read Ginga-Eiyu-Densetsu by Ryu Fujisaki. His comics are very nice!

John: Oh, I see. Which point is so nice?

- (They continued to talk about the comic.) -

John: That's very cool. By the way, I like to take photos of factories. How about you?

Mary: I am not interested in it.

John: I see. (This topic is not good for us.)

Mary: ... (The silent time is made.) 


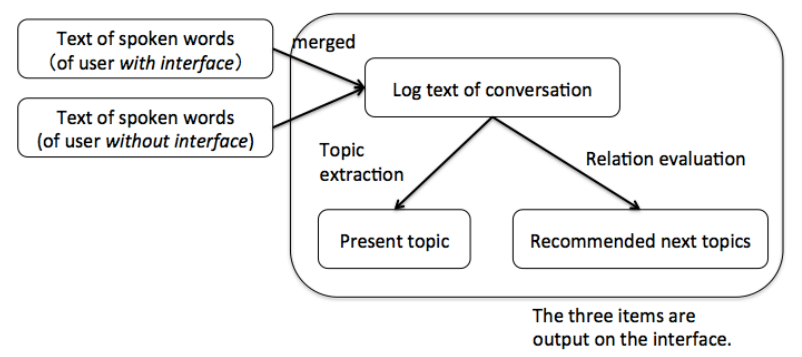

Figure 1: Framework of the proposed method

John can talk with Mary about comic. And John tries to talk about next topic (photo shooting of factory). The next topic is not interested in by Mary. So, he can not continue to talk, then the silent time is made. In this case study, the problem is that John makes a mistake in changing a topic. John chooses photo shooting of factory as a next topic, but the topic is not related to comic for Mary. So, she is not interested in the changed topic. To solve the problem, he should be supported by giving next topics which are related to the present topic.

\subsection{Two functions obtained from the case studies}

We found two problems through the case studies. We will solve the problems by the proposed method. The common point of the two problem is that it is difficult to find next topic what should be talked about. Therefore, we will equip a function to recommend next topics with the proposed method. It is desirable that the recommended topics are related to the present topic. Therefore, the function is to extract the present topic and to evaluate relations between the present topic and next topics.

The proposed system supports conversations of two users who talk for the first time. There are many support systems of conversation by foreigners $[1,2]$ and support system of communications by handicapped people[3, 4]. However, few system supports conversations by people for the first time. Many people are hard to talk with others for the first time. We consider that it is quite required to support conversations by people for the first time.

People who use the Internet often talk with others by using a short message service. They do not hesitate to talk with others on the Internet. However, they often hesitate to talk with others face to face. The proposed method supports the face-to-face talk. Though they have much time to think what they write to say in using the short message service, they do not have much time to think it in face-to-face talk. To support face-to-face conversations, it is required that next topics are recommended in a short time. We try to solve the problem in this research.

\section{Proposed method}

Figure 1 shows the outline of the proposed method. The proposed method supports conversations by two users. The purpose of the proposed method is to support to continue conversations. In order to continue conversations, the proposed method recommends next topics of conversation. 
The proposed method is realized as a system to support to continue conversations. The system has three functions: (1) to make a log text of spoken words, (2) to recommend topics of conversation, and (3) to show the text and topics on an interface. The system uses a Head Mounted Display (HMD) as the interface. One of the users wears the HMD. Therefore, the function (3) is used by the user with HMD though the function (1) and (2) are used by both of the users. We call the user with HMD a user with the interface, and we call the other user a user without the interface.

\subsection{Making a log text of spoken words using a speech recognition machine}

The system makes a log text of spoken words using a speech recognition machine. The system uses a word dictation function equipped with MacBookPro (OS X Yosemite) as the speech recognition machine. The word dictation function starts automatically, and makes a $\log$ text of spoken word inserting new lines every utterances appropriately. The system uses two MacBookPros to dictate words spoken by the two users. We asked the two users to speak slowly and loudly in evaluation experiments of this paper.

The spoken words are dictated separately and two texts of the spoken words are obtained. The texts are uploaded to a server. Then the texts are merged and added other informations. In the server, the two texts are merged into a new text. Time information (when the words are spoken) and user information (who speaks the words) are added to the new text. We call the text a log text of conversation.

\subsection{Extraction of topics of conversation}

Next, the system extracts the present topic of conversation from the log text of conversation. Each topic is represented by a word in this research. The extracted topic is shown on the interface. The user with the interface can use the shown topics to talk with keeping the present topic.

The present topic is extracted from the log text of conversation. A topic is extracted every minutes. If a word is included in many sentences, the word may represent a topic of conversation. The system counts frequencies of a word by two ways. One of the frequency is the number of sentences including a word. The other is the number of sentences in which a word is used as a subject. Then, the two frequencies are multiplied, then a product of the two frequencies is obtained. A word with the highest product is selected as the present topic.

\subsection{Recommendation of next topics}

The system makes a list of next topics that should be talked next. If a topic is mentioned by many people generally, the users of the system can talk about the topic easily. Therefore, we collected topics that have benn talked on Twitter through a Web site (http://tr.twipple.jp). Then, we merged similar topics into a topic. Finally, we obtained a list of topics shown in Table 1. The topics of the list are so general that the users talk easily.

The system recommends next topics by choosing topics from the list shown in Table 1. The next topics should be related to the present topic. Therefore, the system evaluates the relation between the present topic and each topic in the list. Then, highly related topics are recommended to the user with the interface. The system uses hit counts of Web search engine to evaluate the relation. The system makes a query that contains the present topic and a topic shown in Table 1. A topic is selected from sub-category of the list. The query is 
Table 1: List of topics for recommendation. The topics are shown in Japanese for system users. One of the authors translated them in English for this paper.

\begin{tabular}{l|l}
\hline Category & Sub-category \\
\hline 趣味系 (Hobby) & 映画 (movie), 音楽 (music), 読書 (book reading), 漫画 (comic), 旅 \\
& 行 (trip), スポーツ (sport), ゲーム (game), 楽器 (instrument) \\
\hline プロフィール系 (Profile) & 名前 (name), 誕生日 (birthday), 年齡 (age), 血液型 (blood type), 出 \\
& 身地 (hometown), 家族 (family), 健康 (health), 髮型 (hair style), 体 \\
& 型 (person's figure) \\
\hline 衣食住 (food, clothing, and housing) & 通勤 (commuting to office), 通学 (commuting to school), 地域 (dis- \\
& trict), 食べ物 (food), 休日 (holiday), 季節 (season), 天気 (weather) \\
\hline 学生生活 (school life) & 大学 (university), 授業 (lesson), 経験 (experience), 高校 (high \\
& school), 中学校 (junior high school), 小学校 (elementary school), \\
& 部活動 (club), バイト (part-time job), 先生 (teacher) \\
\hline テレビ番組 (TV program me) & アニメ (animation), ドラマ (drama), ジャニーズ,AKB, お笑い, ク \\
& イズ (quiz), 俳優 (actor), 女優 (actress) \\
\hline 興味関心 (interest) & 流行 (trend), ニュース (news), 異性 (the opposite sex), ファッショ \\
& ン (fashion), 有名人 (famous person) \\
\hline
\end{tabular}

input to a Web search engine. The system uses bing as a Web search engine. If the number of hit counts is higher, the two topics are evaluated as related strongly. The proposed system recommends five topics of high number of hit counts as the next topics. The next topics are changed every minutes.

\subsection{Interface of the proposed system}

Figure 2 shows the interface of the system. The interface is shown through a display of HMD. The interface shows three items: spoken words, the present topic, and the next topics recommended by the system. The spoken words are shown on the left side of the interface. The words in the left aligned balloon are by the user with the interface. The words in the right aligned balloon are by the user without the interface. The user of the interface can grasp the flow of conversation by watching the spoken words. The present topic is shown on the upper of the right side. The user of the interface can grasp what topic they now talk. The next topics are shown on the bottom of right side. The user of the interface can choose a next topic to continue a conversation.

\section{Evaluation experiments}

We evaluated the proposed system in experiments. The purpose of the system is to support to continue conversations. We prepared a system equipped with a comparative method, and compared the efficiency of the two systems for the purpose.

\subsection{Procedures}

The experimental procedures are explained in the following 1. through 8 .

1. An experimenter (the second author) gathered 10 participants.

2. Each participant answered an advance questionnaire. 


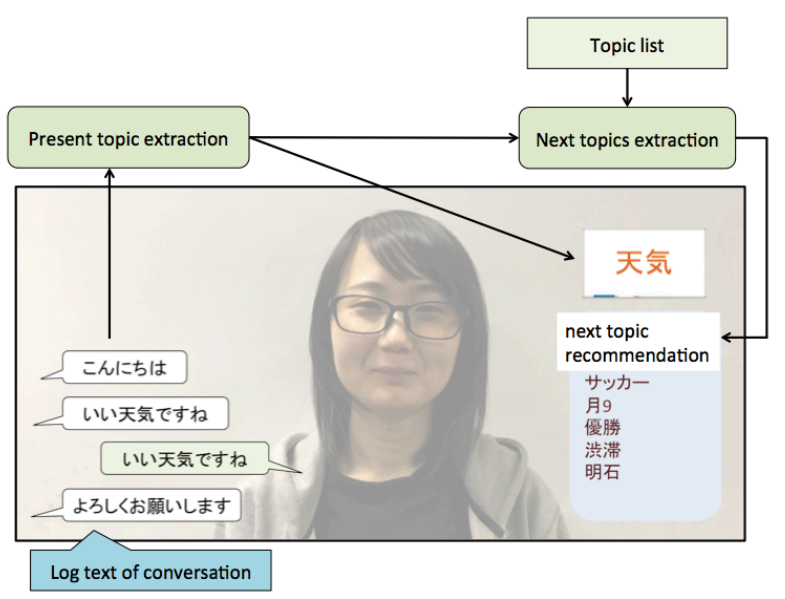

Figure 2: Interface of the system to support to continue conversations.

3. Referring the results of the advance questionnaire, the experimenter divided the participants into two groups: an experimental group and a control group.

4. The experimenter made pairs of two participants in each group. One of the participants in each pair was selected as a user of the interface.

5. For the first one minute, the two participants in each group introduced themselves each other.

6. Then, the two participants started a conversation about a topic as they liked.

7. They kept the conversation, then stopped it after 10 minutes from the procedure 5 .

8. The two participants answered a post questionnaire.

Each participant wore a bone conductive microphone to record his/her voice data. To collect a log text of conversation, the participants introduced themselves in the procedure 5 . Self-introduction is easy for most of the participants. We asked the participants to suppose that their partner is a family member of their boyfriend/girlfriend. Because we needed to avoid making the silent time of conversation willingly by the participants. We explained the items of the interface only to a participant of the interface. We asked a participant without the interface not to change a topic actively.

\subsubsection{Participants}

We collected 10 candidates of participant of the evaluation experiments. The 10 candidates answered the advance questionnaire. The purpose of the advance questionnaire was to evaluate the ability of conversation of each candidate. There were four questions in the advance questionnaire. The questions are shown in Table 2. The candidates answered each question with Absolutely Yes:5, Yes:4, Neither Yes or Neigher No:3, No:2, and Absolutely No:1. We removed candidates who answered Absolutely Yes:5 or Absolutely No:1 for a question. The number of rest candidates was seven. We set them as the participants of the evaluation experiments. 
Table 2: Questions of the advance questionnaire. The third author gave English translations for the paper.

\begin{tabular}{l|l}
\hline Question 1. & $\begin{array}{l}\text { 普段の会話では、自分から話題をふる、あるいは話題を変える方ですか? (Do you often } \\
\text { turn topics in conversations?) }\end{array}$ \\
\hline Question 2. & $\begin{array}{l}\text { 普段の会話で、会話中に、今の話題を意識していますか? (Do you often keep the present } \\
\text { topic in your mind in a conversation?) }\end{array}$ \\
\hline Question 3. & $\begin{array}{l}\text { 普段の会話で、会話中に、次の話題を意識していますか?(Do you often keep the next topic } \\
\text { in your mind in a conversation?) }\end{array}$ \\
\hline Question 4. & $\begin{array}{l}\text { 今まであまり話したことがい人と会話する時に、話題に困る事はありますか? (Do you } \\
\text { find easily topics in conversations with unfamiliar persons?) }\end{array}$ \\
\hline
\end{tabular}

Table 3: Answers of the advance questionnaire by the seven participants.

\begin{tabular}{l|rrrrr}
\hline Experimental group & $\# 1$ & $\# 2$ & $\# 3$ & $\# 4$ & $\# 5$ \\
\hline Question 1 & 4 & 4 & 3 & 4 & 3 \\
Question 2 & 5 & 4 & 4 & 1 & 2 \\
Question 3 & 3 & 4 & 2 & 1 & 2 \\
Question 4 & 2 & 3 & 4 & 3 & 4 \\
\hline Control group & $\# 1$ & $\# 2$ & $\# 3$ & $\# 4$ & $\# 5$ \\
\hline Question 1 & 4 & 4 & 3 & 3 & 2 \\
Question 2 & 5 & 4 & 4 & 5 & 3 \\
Question 3 & 3 & 4 & 2 & 5 & 4 \\
Question 4 & 2 & 3 & 4 & 5 & 4 \\
\hline
\end{tabular}

We divided the participants into two groups. Each group had the participants of almost equal conversation ability. Table 3 shows the answers of the advance questionnaire by the seven participants. The \#1, \#2, and \#3 participant were the same in the experimental group and the control group.

\subsubsection{Comparative system}

We prepared a comparative system for the evaluation experiments. The comparative system was a system that was removed the topic recommendation function from the system of the proposed method. The comparative system also had other functions of the system of the proposed method.

\subsubsection{Post questionnaire}

After conversations, the participants answered a post questionnaire. Table 4 shows questions of the post questionnaire. The participants answered each question as same as the advance questionnaire. The experimental group answered all four questions although the control group answered two questions: Question 1 and Question 2.

\subsection{Evaluation data}

We took the following data for evaluation of the two system: (1) the number of spoken characters, (2) the number of changed topics, and (3) answers of the post questionnaire. 
Table 4: Questions of the post questionnaire. The third author gave English translations for the paper.

\begin{tabular}{l|l}
\hline Question 1 & $\begin{array}{l}\text { 会話で話題に困る事はありませんでしたか? (Did you find easily which topic you } \\
\text { should talk about?) }\end{array}$ \\
\hline Question 2 & $\begin{array}{l}\text { 表示された「会話の話題」は適切に話題を表していましたか?(Were the present topics } \\
\text { extracted by the system correct?) }\end{array}$ \\
\hline Question 3 & $\begin{array}{l}\text { 表示された「推薦話題」は次の話題の選択に役立ちましたか?(Were the next topics } \\
\text { recommended by the system useful to select next topic?) }\end{array}$ \\
\hline Question 4 & $\begin{array}{l}\text { 表示された「推薦話題」は「会話の話題」に関係していましたか? (Were the next } \\
\text { topics related to the present topics?) }\end{array}$ \\
\hline
\end{tabular}

Table 5: Number of Spoken Characters by participants.

\begin{tabular}{l|r|r|r|r|r|r}
\hline Experimental group & $\# 1$ & $\# 2$ & $\# 3$ & $\# 4$ & $\# 5$ & average \\
\hline Number & 930 & 2097 & 515 & 1347 & 1356 & 1249 \\
\hline Control group & $\# 1$ & $\# 2$ & $\# 3$ & $\# 4$ & $\# 5$ & average \\
\hline Number & 670 & 1197 & 393 & 670 & 748 & 471.6 \\
\hline
\end{tabular}

\section{Experimental Results}

This section shows experimental results and discusses them.

\subsection{Number of spoken characters}

Table 5 shows the numbers of spoken characters by the participants. The average of spoken characters of the experimental group was bigger than that of the control group.

Table 6 shows the numbers of spoken characters and the rates of spoken characters. Those by the participants with the interface and those by the participants without the interface are shown respectively. The averages of spoken characters of the experimental group were 770.4 and 478.6 although those of the control group were 576.4 and 159.2. The numbers of spoken characters of the experimental group were bigger.

Each pair of the two groups made a conversation for 10 minutes. In the same time limitation, the experimental group made the number of spoken characters bigger. The results

Table 6: Numbers and rates(\%) of spoken characters by each participant.

\begin{tabular}{l|r|r|r|r|r|r}
\hline Experimental group & $\# 1$ & $\# 2$ & $\# 3$ & $\# 4$ & $\# 5$ & avg. \\
\hline$\#$ with interface & 561 & 1412 & 575 & 733 & 720 & 770.4 \\
rate with interface & 60.3 & 67.3 & 82.7 & 54.4 & 53.0 & 63.5 \\
\hline \# without interface & 369 & 685 & 89 & 614 & 636 & 478.6 \\
rate without interface & 39.6 & 32.6 & 17.2 & 45.5 & 46.9 & 36.4 \\
\hline Control group & $\# 1$ & $\# 2$ & $\# 3$ & $\# 4$ & $\# 5$ & avg. \\
\hline \# with interface & 508 & 871 & 298 & 595 & 610 & 576.4 \\
rate with interface & 75.8 & 72.7 & 75.8 & 88.8 & 81.5 & 78.9 \\
\hline \# without interface & 162 & 326 & 95 & 75 & 138 & 159.2 \\
rate without interface & 24.1 & 27.2 & 24.1 & 11.1 & 18.4 & 21.1 \\
\hline
\end{tabular}


Table 7: Number of changed topics in a conversation

\begin{tabular}{l|r|l|r}
\hline Experimental group & \# of changed topics & Control group & \# of changed topics \\
\hline$\# 1$ & 8 & $\# 1$ & 6 \\
$\# 2$ & 8 & $\# 2$ & 4 \\
$\# 3$ & 6 & $\# 3$ & 3 \\
$\# 4$ & 5 & $\# 4$ & 1 \\
$\# 5$ & 2 & $\# 5$ & 0 \\
\hline average & 5.8 & average & 2.8 \\
\hline
\end{tabular}

Table 8: Transition of topics of participants of the experimental group. The participants talked in Japanese. The third author translated obtained topics into English ones for the paper.

\begin{tabular}{|c|c|c|}
\hline Time & Present topic & Recommended topics \\
\hline $1 \mathrm{~min}$. & 東日本 (east Japan) & $\begin{array}{l}\text { 大学 (university), 部活動 (club), 高校 (high school), ニュース } \\
\text { (news), 授業 (lessons) }\end{array}$ \\
\hline $2 \mathrm{~min}$, & 変態 (perversion) & $\begin{array}{l}\text { ゲーム (game), 女優 (actress), 大学 (university), 高校 (high school), } \\
\text { 部活動 (club) }\end{array}$ \\
\hline $3 \mathrm{~min}$. & ニュース (news) & $\begin{array}{l}\text { 高校 (high school), 健康 (health), 誕生日 (birthday), 食べ物 (food), } \\
\text { 大学 (university) }\end{array}$ \\
\hline $4 \mathrm{~min}$. & 今日 (today) & $\begin{array}{l}\text { 健康 (health), 経験 (experience), 休日 (holiday), 通学 (commuting } \\
\text { to school), スポーツ (sport) }\end{array}$ \\
\hline $5 \mathrm{~min}$. & 松岡 (Matsuoka) & $\begin{array}{l}\text { 漫画 (comic), ドラマ (drama), 休日 (holiday), クイズ (quiz), 健康 } \\
\text { (health) }\end{array}$ \\
\hline $6 \mathrm{~min}$. & 予定 (schedule) & $\begin{array}{l}\text { 旅行 (trip), 天気 (weather), 女優 (actress), アニメ (animation), ドラ } \\
\text { マ (drama) }\end{array}$ \\
\hline $7 \mathrm{~min}$. & 画像 (image) & $\begin{array}{l}\text { 食べ物 (food), 通勤 (commuting to office), 中学校 (junior high } \\
\text { school), 出身地 (hometown), 地域 (district) }\end{array}$ \\
\hline $8 \mathrm{~min}$. & インターネット (Internet) & $\begin{array}{l}\text { ドラマ (drama), 映画 (movie), 名前 (name), 流行 (trend), 通勤 (com- } \\
\text { muting to office) }\end{array}$ \\
\hline $9 \mathrm{~min}$. & 今日 (today) & $\begin{array}{l}\text { 先生 (teacher), 休日 (holiday), クイズ (quiz), 健康 (health), 楽器 } \\
\text { (instrument) }\end{array}$ \\
\hline $10 \mathrm{~min}$. & 今日 (today) & $\begin{array}{l}\text { 季節 (season), 休日 (holiday), 楽器 (instrument), クイズ (quiz), 健 } \\
\text { 康 (health) }\end{array}$ \\
\hline
\end{tabular}

indicate that the proposed method can support to continue conversations.

In Table 6, the difference between the rates of the experimental group was $27.1 \%$ $(=65.4 \%-36.4 \%)$ although that of the control group was $57.8 \%(=78.9 \%-21.1 \%)$. The result indicates that the proposed method supports users to obtain equal chances to speak.

\subsection{Number of changed topics in a conversation}

Table 7 shows the numbers of changed topics in each conversation. The average of changed topics of the experimental group was 5.8 although that of the control group was 2.8. The average of the experimental group was bigger $(t=0.025, \mathrm{p}<0.05)$. The participants of the experimental group could use the function of next topic recommendation. The bigger average indicates that the function of next topic recommendation supports the participants to change topics frequently. Table 8 shows a part of transition of topics and recommended topics of participants of the experimental group. 
Table 9: Answers of the post questionnaire

\begin{tabular}{l|rrrrr}
\hline Experimental group & $\# 1$ & $\# 2$ & $\# 3$ & $\# 4$ & $\# 5$ \\
\hline Question 1 & 4 & 5 & 1 & 4 & 5 \\
Question 2 & 1 & 4 & 3 & 3 & 2 \\
Question 3 & 4 & 4 & 2 & 4 & 5 \\
Question 4 & 2 & 4 & 2 & 3 & 5 \\
\hline Control group & $\# 1$ & $\# 2$ & $\# 3$ & $\# 4$ & $\# 5$ \\
\hline Question 1 & 1 & 3 & 1 & 2 & 2 \\
Question 2 & 1 & 4 & 2 & 2 & 2 \\
\hline
\end{tabular}

\subsection{Answers of the post questionnaire}

Table 9 shows the answers of the post questionnaire. For all questions, the participants of the experimental group evaluated the system of the proposed method higher.

\section{Conclusion}

This paper proposes a conversation support method. We supposed that recommending next topics of conversation can support to continue conversations. The proposed method extracts a present topic from a log text of conversation, then recommends next topics relating to the present topic. We evaluated the proposed method in evaluation experiments. We prepared a comparative method to evaluate the function of recommending next topics. Experimental results indicated that the proposed method could support to continue conversations by recommending next topics. We also found that the proposed method supported users to obtain equal chances to speak. As the future work, we will confirm the efficiency of evaluating relations between the present topic and next topics.

\section{References}

[1] R. Inaba, Y. Murakami, A. Nadamoto, T.Ishida, Multilingual Communication Support Using the Language Grid, Intercultural Collaboration, Vol. 4568 of the series Lecture Notes in Computer Science, pp.118-132, (2007).

[2] K. Imoto, M. Sasajima, T. Shimomori, N. Yamanaka, M. Yajima, and Y. Masai, A multi modal supporting tool for multi lingual communication by inducing partner's reply, Proceedings of the 11th international conference on Intelligent user interfaces, pp. 330-332, (2006).

[3] A, Tamura, S. Okada, T. Harada, M. Sato, K. Nitta, HAPPicom: Haptic Pad for Impressive Text Communication ACM International Conference on Intelligent User Interfaces, (2013).

[4] M. Benali-Khoudja, M. Hafez, A. Sautour, and S. Jumpertz, Towards a new tactile language to communicate emotions. International Conference on Mechatronics and Automation, Vol.1, pp. 286-291, (2005). 